Georgetown University Institutional Repository http://www.library.georgetown.edu/digitalgeorgetown

The author made this article openly available online. Please tell us how this access affects you. Your story matters.

McNELIS, C. 'Looking at the Forest? The Silvae and Roman Studies: Afterword', Arethusa, Volume 40, Number 2, Spring 2007, pp. 279-284

doi: 10.1353 /are.2007.0017

Collection Permanent Link: http://hdl.handle.net/10822/555443

(C) 2007 The Johns Hopkins University Press

This material is made available online with the permission of the author, and in accordance with publisher policies. No further reproduction or distribution of this copy is permitted by electronic transmission or any other means. 


\title{
LOOKING AT THE FOREST? THE SILVAE AND ROMAN STUDIES: AFTERWORD
}

\author{
CHARLES MCNELIS
}

There is nothing else like the Silvae in extant Roman literature in terms of diversity and range. Statius's thirty-two poems contain, for example, emotional addresses — both sad and celebratory — to family and friends; praise of physical objects (statues, baths, villas, and a road) and people, including the emperor Domitian; and discussions of animals (and even a tree). Such a wide variety of themes implicates topics such as dining, nature, imperial power, family life, sexuality, patronage, marriage, death, rhetoric, education, and the arts, just to name a few. The poems, then, contain points of interest for almost anyone interested in imperial Rome, and consequently deserve the attention and interest of many critics.

Fortunately, the Silvae are about as accessible now as they ever have been. There are new translations, and the past thirty years or so have witnessed the publication of editions and commentaries that have been badly needed to help explain the challenging language employed by Statius. These essential research tools will continue to open up Statius's poetry to different kinds of approaches ranging from prosopographical studies to those employing sociological theory; from formalist studies of his language and generic antecedents to readings of imperial culture in both the public and private spheres; from intertextual readings of the poems in light of earlier poets - most notably Virgil, Ovid, and Lucan — to those focusing on contemporary domestic decoration. This wide array of scholarship is not simply a case of post-modern readers running amuck and finding whatever they need (or want) in a set of poems. Rather, it is clear that the Silvae will sustain all types of research. And these developments will likely continue, since, at least in the United States, some of the Silvae have recently appeared on 
reading lists in graduate programs. It seems as though the poems are here to stay for some time.

While no one can presume to know the sorts of questions that will be asked in the future of the Silvae, it is reasonable to hope that future criticism will continue along lines similar to those of recent enquiry. That is, recurring study of the poems through the lens of a broad range of literary, social, and historical approaches will shed more light on Statius's ouevre as well as imperial culture. These numerous possibilities for approaching the Silvae are exciting, but they also seriously challenge readers in that the poems break down the boundaries between many of the disciplines in the field. Synthetic approaches and methodologies that build upon the foundations that have been laid in recent years will thus need to continue. ${ }^{1}$ And as the bibliography on Statius encouragingly multiplies, there is reason to be optimistic that this will be the case. To bring the Silvae further into the classics mainstream, however, the poems will need to be seen as important by a broader range of scholars than just those working on imperial Latin poetry, and in this regard, it may be useful to outline some broad trends in Roman studies to which Statius's poems can contribute.

The idea of Hellenism - that is, of Rome's reception of the Greek world in realms as diverse as literature, visual art, politics, and philosophy, to name just a few-has been among the most significant advances that have been made in recent years in the study of imperial Rome. In fact, the topic is so rich that Cambridge University Press has initiated a series entitled "Greek Culture in the Roman World" that focuses on various aspects of Greek culture under the Roman empire and the responses of the Greek world to imperial Rome. Cultural interaction, of course, is at least a two-way street, and Rome's reception of Greece matters quite a bit in this dynamic. And while Greece and its import for Rome has always been a significant object of study, recent scholarship on the material culture-and particularly the houses-found on the Bay of Naples in sites such as Pompeii and Herculaneum has opened up a whole new series of questions by articulating the strategies by which Romans, in order to mark their status as Romans, made calculated uses of Greek culture. ${ }^{2}$ Since the Silvae are virtually of the

1 For some scholarship that represents these sorts of readings, see, for example, the bibliography cited in n. 2 of the Introduction to this volume.

2 Zanker 1979 and Wallace-Hadrill 1994 are two prominent examples of this kind of work. 
same period as the eruption of Vesuvius, and since so many of the poems concern villa culture, the poems will both illuminate and be illuminated by the material evidence and what it has to offer about imperial Roman appropriations of the Greek past. Indeed, perhaps no set of texts crystallizes these dynamics better than the Silvae, the product of a Hellenized Neapolitan who associated with the upper crust of Roman society. ${ }^{3}$

This dovetailing of literary and material evidence provides unparalleled opportunities to understand, for example, the production and consumption of literature in the imperial Roman world. After all, a villa brought together the economic, social, and intellectual forces that generated nearly all of Roman artistic culture, and the Silvae, taken in conjunction with more familiar sources like Pliny, have much to offer on topics such as the role of the arts among villa owners. Indeed, sites such as the Villa of the Papyri, which was buried by the pyroclastic flow that overwhelmed Herculaneum and preserved all sorts of sculpture as well as the Epicurean writings of Philodemus, must have witnessed much of the same kinds of intellectual activity that appear in many of the Silvae. Consideration of such a site in relation to Statius's poems will surely enhance our understanding of both the literary and material remains. Evidence from other sites will also bear upon Statius's employment of, for example, myth and the arts, as well as attitudes towards nature and gender. The role of all kinds of Greek culture on the Bay of Naples (and even in Roman life) may be a familiar story, but evidence from the Silvae offers ways to contribute to and develop that narrative. In turn, recent perspectives on that narrative will benefit any reading of Statius's poems.

To move to social history writ large, cultural issues and ideas such as power, patronage, spectacle, dining, gender, and law have been receiving intense analysis from all sorts of critics of ancient Rome. As some of the papers contained in this volume show, these very issues are all in play in the Silvae, and the poems thus offer important insights into the workings of imperial Roman society. While topics such as patronage and the social status of individuals mentioned in the Silvae have already benefited from scholarly studies, ${ }^{4}$ the surface has just been scratched in the case of other concerns such as sexuality and gender. A few of the Silvae concern eunuchs and pueri delicati, for example, and these poems would be

3 Hardie 1983 brilliantly explicates the cultural blend of the Silvae.

4 Nauta 2002 is a recent study of this topic that has a rich tradition. 
profitably considered in light of current discussions about the constructions and definitions of masculinity, gender, and sexuality in the Roman world. In fact, Statius has recently been shown to engage with these very topics in extremely interesting ways in his Achilleid (Heslin 2005), and similar dynamics seem to be at work in the occasional poems.

One more trend in Roman studies to which the Silvae are relevant is primarily literary in nature: the study of the relationship between one text and its antecedents. This idea has been a major focus of Latin poetry for some time now, but recent approaches are unquestionably responsible for much of the renewed interest in Flavian literature, including the Silvae. Central to this renewed critical interest in the literature of this period is the awareness that later texts may offer powerful perspectives on earlier, oftentimes canonical, texts. Critics of Ovid, for instance, have demonstrated how deeply and brilliantly Ovid read the Aeneid, and much the same is happening now with Statius. Reading along these lines illustrates both the significant influence of the canonical text(s) as well as the diverse ways that these texts could be read, and such insights offered by serious artists are worth our attention. The Silvae, which engage a powerful and rich literary tradition, confront this previous literature in compelling ways that will enhance our appreciation of the earlier texts.

This literary endeavor has cultural resonance as well. Whatever view one takes of Ovid's Metamorphoses, for example, it is now recognized that the poem's reworking of the Aeneid bears upon central questions of the Augustan age. When Lucan reworks the Aeneid, it seems that he responds to the imperial regime that the Aeneid could only speculate about. The Silvae, of course, are not epic, and their generic status is remarkably difficult to pin down. Nonetheless, Statius's use of the epic past is persistent, and in this sense, the formal characteristics of the Silvae raise important cultural questions. Epic is often concerned with the proper balance, for example, between collective and individual interests. And it does so from a very broad perspective; that is, from the insights and actions of individuals who have an enormous impact upon the rest of society. The Silvae, with their personal, friendly, and even intimate portrayals of relationships that need not affect geopolitics, look at questions that help to define life from different perspectives, whether it be the view of a husband writing to his wife, a son to his father, or friend to friend. At the same time, however, poems to or about Domitian do bring in the world of politics, thus juxtaposing public and private in a more personal and less authoritative mode than that found in epic. 
These diverse tones of Statius's poems raise important questions about, for instance, narrative authority and other types of authority as well.

Ultimately, the best readings of the Silvae will encompass both literary-historical and cultural approaches. And indeed, these methods are not all that distant at moments. For example, Andrew Wallace-Hadrill suggests (1994.17-26) that the world of the Roman house was defined in part by "allusion." That is, the homeowner attempted to create impressions by incorporating various images of public life_-such as temples_-into his private domestic decoration. Greek culture and myth are significant components of this domestic "allusion," and it is not hard to see how literary allusion often works in a similar way to evoke Greek culture as well as aspects of public and private life. Interpreting the house and/or a poem depends on the recognition of what kind of world is being evoked and how that evocation sits within its particular context. The Silvae are exciting in part because they often involve multiple layers of allusion, with the first being the more conventional establishment of a relationship between two texts, the second involving the connection between the occasional poem and the objects it may be discussing. The challenge here lies in both the control of the different types of evidence and in gauging how the new product incorporates the older. But the results of such enquiries will surely enhance our awareness of the literary and cultural richness of the Silvae.

In order to continue to advance our readings of these poems, however, there are at least two major obstacles that will need to be addressed by critics. For all the thrust of this essay on the social, historical, or cultural aspects of the Silvae, critics, as the papers in this volume emphasize, need to avoid undervaluing or even discounting the artistic programmes that drive Statius's poems. Instead, Statius's poetic strategies need to be unpacked and considered in light of social practices. To use an analogy, one would be hard pressed to find critics who would suggest that Pindar-a poet with whom Statius shares a number of similarities such as difficult language, an occasional context that depends upon social and/or political elites, and a deep interest in securing patronage_-simply reacts to and represents the Greek world that he depicts. Rather, Pindar constructs his own argument about social norms (see, for example, Kurke 1991). In the case of the Silvae, such an enquiry about the relationship between Statius and the society he depicts will result in varying assessments of, for instance, power and patronage; after all, so much of the energy behind the renewed interest in imperial literature stems from lively debates about the construction of 
authority in the Roman world, and we should not expect the Silvae to be exempt from these arguments. As long as these debates enhance our understanding of the poems and their handling of - not simply reaction to- their social context, so much the better.

Perhaps a corollary to that obstacle of not taking Statius's poetic strategies seriously is the question of his style. Traditionally, much imperial Latin has been regarded with disdain (authors like Juvenal, Tacitus, and, more recently, Apuleius are exceptions), and the reputedly poor style of the period is typically offered as a major reason. If this critique is not addressed — either directly or indirectly—by critics, then skepticism about Statius's poetry and its content will continue. The charge of poor style is, to say the least, questionable, since Statius was held up as a model of style by Dante (de Vulgari Eloquentia 2.6.7), ${ }^{5}$ who wrote more significant Latin than have most critics of Latin literature. Nonetheless, even in the Renaissance, Poliziano, one of the best Latinists of his period, argued against criticism of authors such as Statius and Quintilian on stylistic grounds. So the disparagement of imperial style is old, and, as the varying assessments of some impressive Latinists show, subjective. Dante and Poliziano, however, are two inspirational allies for those arguing against the entrenched modern view. Serious reevaluation of this issue is still wanting, and without it, the charge is unlikely to go away even as a generation of scholars who will have read some of these poems in graduate school enters into the profession. And this cloud of suspicion will continue to hinder advances.

The Silvae, as John Henderson puts it earlier in this volume, are poems of interface and thus important for today's classics and its emphasis upon interdisciplinarity. And in this sense, it is good that these poems are being brought more and more to the attention of students, some of whose interests presumably lie outside of literature per se. At the same time, the research of those interested in literature and its philological basis will continue to be indispensable. The more these different types of study are brought together, the better will be our understanding of many aspects of Statius's Silvae and their presentation of imperial Rome.

\section{Georgetown University}

5 Though Dante must be speaking about Statius's epics, my point holds, since modern prejudices are not based upon distinctions between his occasional and epic poetry. 